\title{
ANÁLISE \\ MULTISSEMIÓTICA \\ E ENSINO DE LÍNGUA \\ PORTUGUESA NA EDUCAÇÃO \\ BÁSICA: DAS TEORIAS \\ À PROPOSIÇÃO \\ DIDÁTICA
}

\section{ANÁLISIS MULTISEMIÓTICO Y ENSEÑANZA DE LA LENGUA PORTUGUESA EN EDUCACIÓN BÁSICA: DE LAS TEORÍAS A LA PROPUESTA DOCENTE}

\author{
MULTISEMIOTIC ANALYSIS AND PORTUGUESE LANGUAGE TEACHING IN BASIC \\ EDUCATION: FROM THEORIES TO TEACHING PROPOSITION
}

Fernanda Maria Almeida dos Santos* Universidade Federal da Bahia

RESUMO: Na sociedade contemporânea, a ampliação dos processos comunicativos, propiciada, sobretudo, pelo desenvolvimento das tecnologias digitais, requer professores preparados para trabalhar com o texto não apenas numa perspectiva linguística, mas também semiótica. No entanto, ainda é um desafio, para muitos docentes, promover a didatização dos conteúdos teóricos e desenvolver o ensino de Semiótica a partir de uma análise integrada das semioses em textos multimodais. Nesse sentido, o presente artigo - embasado na Teoria Semiótica de Peirce, bem como na Linguística Sistêmico-Funcional de Halliday e na Semiótica Social - objetiva apresentar um modelo didático para o trabalho com análise multissemiótica na educação básica. Argumenta-se, a partir de uma proposta elaborada com base nos fundamentos metodológicos da Pedagogia dos Multiletramentos (NLG, 1996; COPE; KALANTZIS, 2009) e nos postulados da Gramática do Design Visual (KRESS; VAN LEUWEEN, 2006 [1996]), que estratégias de aprendizagem desenvolvidas por meio da experimentação, conceitualização, análise e aplicação de conhecimentos relativos aos sistemas representacionais, interativos e composicionais podem contribuir para a compreensão global dos textos multimodais. PALAVRAS-CHAVE: Semiótica Social. Multimodalidade. Língua Portuguesa. Ensino.

\footnotetext{
* Docente de Língua Portuguesa do Instituto de Letras da Universidade Federal da Bahia (UFBA) e do Programa de Mestrado Profissional em Letras da UFBA. Doutora em Língua e Cultura pela UFBA. E-mail: fernandasantos83@hotmail.com.
} 
RESUMEN: En la sociedad contemporánea, la expansión de los procesos comunicativos, provocada, sobre todo, por el desarrollo de las tecnologías digitales, requiere docentes preparados para trabajar con el texto no solo en una perspectiva lingüística, sino también semiótica. Sin embargo, sigue siendo un desafío para muchos docentes promover la didáctica de los contenidos teóricos y desarrollar la enseñanza de la Semiótica a partir de un análisis integrado de semiosis en textos multimodales. En este sentido, este artículo basado en la Teoría Semiótica de Peirce, así como la Lingüística Sistémico-Funcional de Halliday y la Semiótica Social - pretende presentar un modelo didáctico para trabajar con el análisis multisemiótico en la educación básica. Se argumenta, a partir de una propuesta elaborada con base en los fundamentos metodológicos de la Pedagogía de la Multiliteracidad (NLG, 1996; COPE; KALANTZIS, 2009) y en los postulados de la Gramática del Diseño Visual (KRESS; VAN LEUWEEN, 2006 [1996]), que las estrategias de aprendizaje se desarrollan a través de la experimentación, conceptualización, análisis y aplicación de conocimientos relacionados con la representación, la interacción y los sistemas de composición pueden contribuir a la comprensión global de textos multimodales.

PALABRAS CLAVE: Semiótica social. Multimodalidad. Lengua portuguesa. Enseñando.

ABSTRACT: In contemporary society, the expansion of communicative processes, brought about, above all, by the development of digital technologies, requires teachers prepared to work with the text not only in a linguistic perspective, but also in semiotics. However, it is still a challenge for many teachers to promote the didacticization of theoretical contents and to develop Semiotics teaching from an integrated analysis of semioses in multimodal texts. In this sense, this article - based on Peirce's Semiotic Theory and on Halliday's Systemic-Functional Linguistics and Social Semiotics, aims to present a didactic model for working with multisemiotic analysis in basic education. It is argued, based on a proposal prepared on the methodological foundations of Pedagogy of Multiliteracies (NLG, 1996; COPE; KALANTZIS, 2009) and in the postulates of the Grammar of Visual Design (KRESS; VAN LEUWEEN, 2006 [1996]), that learning strategies developed through experimentation, conceptualization, analysis and application of knowledge related to representational, interactive and compositional systems can contribute to the global understanding of multimodal texts.

KEYWORDS: Social Semiotics. Multimodality. Portuguese Language. Teaching.

\section{INTRODUÇÃO}

Na sociedade hodierna, a expansão e a popularização do acesso às tecnologias digitais têm contribuído para a ampliação dos processos comunicacionais, bem como para o surgimento e a propagação de diferentes linguagens visuais, sonoras, espaciais, multimodais etc. Nesse sentido, as atividades de ensino e aprendizagem de Língua Portuguesa precisam estar alinhadas às necessidades dos sujeitos pós-modernos e, obviamente, às novas formas de combinação dos signos para a constituição da linguagem. Por isso, o docente deve estar preparado para lidar não somente com os aspectos verbais (orais e escritos) da língua, mas, sobretudo, para trabalhar com a linguagem numa perspectiva multissemiótica.

A Semiótica ${ }^{1}$ assume, na verdade, um lugar central no ensino das práticas de linguagem, tendo em vista que - por promover o estudo e a compreensão dos diferentes signos que constituem um texto - é transversal às práticas de leitura, oralidade e produção de textos. Apesar disso, no contexto escolar, o ensino de Semiótica ainda é um desafio para boa parte dos docentes. Essa situação está relacionada, por um lado, às limitações na formação inicial de professores de Língua Portuguesa, uma vez que os currículos dos cursos de Licenciatura em Letras no Brasil oferecem poucas disciplinas dessa área (ou, até mesmo, nenhuma)². Além disso, por outro lado, apenas recentemente - com a publicação da Base Nacional Comum Curricular (BNCC) - é que a legislação educacional brasileira apresenta algumas orientações para o trabalho com análise semiótica na educação básica. Mas esse documento, de caráter normativo, tem apenas o papel de definir o conjunto orgânico e progressivo de aprendizagens essenciais que devem ser desenvolvidas

\footnotetext{
${ }^{1}$ Neste artigo, ao se referir ao campo do conhecimento, o termo "semiótica" é grafado com inicial maiúscula [Semiótica]. Já sua forma adjetiva, indicando um tipo de abordagem (como em "análise semiótica”), é apresentada com inicial minúscula [semiótica].

${ }^{2} \mathrm{Na}$ seção 3 deste trabalho, serão mencionados alguns dados relativos aos cursos de Licenciatura em Letras nas Universidades públicas do estado da Bahia.
} 
pelos estudantes nas diferentes etapas e modalidades da educação básica. Não promove, por isso, uma didatização de conhecimentos teóricos nem apresenta estratégias didáticas que possam ser utilizadas em sala de aula.

Sendo assim, um questionamento ainda sem resposta no campo da didática da Língua Portuguesa é: Como promover o ensino de Semiótica no contexto escolar, desenvolvendo uma análise integrada das semioses em textos multimodais, a partir do que propõem as teorias e os documentos educacionais? No intuito de apresentar algumas respostas para esse questionamento, sem esgotar os caminhos e as possibilidades para o ensino, o artigo objetiva apresentar uma proposta didática para o trabalho com análise multissemiótica na educação básica, tendo como público-alvo estudantes do ensino médio.

Inicialmente, o trabalho apresenta um breve histórico sobre os estudos de Semiótica, enfatizando as contribuições de Peirce para a construção dos principais fundamentos que norteiam as pesquisas nessa área do conhecimento. Em seguida, expõe como a Semiótica Social e a Teoria da Multimodalidade, por meio dos pressupostos da Linguística Sistêmico-Funcional de Halliday, promovem uma ampliação do olhar da ciência Semiótica em relação ao universo dos signos. E, no intuito de atrelar as teorias às práticas educacionais, o texto analisa as contribuições da Base Nacional Comum Curricular para o ensino de Semiótica, bem como problematiza alguns elementos contidos no documento. E, por fim, apresenta uma proposta didática para o trabalho com análise de textos multimodais, embasada, por um lado, na Pedagogia dos Multiletramentos (NLG, 1996; COPE; KALANTZIS, 2009) e, por outro, nos pressupostos da Gramática do Design Visual (KRESS; VAN LEUWEEN, 2006 [1996]). Mas é importante ressaltar que não se trata de uma proposta específica para o trabalho com um gênero textual/discursivo. O que se pretende, na verdade, por meio deste artigo, é apresentar um modelo didático global que possa fundamentar a elaboração de propostas mais específicas para o trabalho com diferentes gêneros multimodais em aulas ministradas para discentes do ensino médio.

Espera-se, com isso, demonstrar, num universo múltiplo, uma possibilidade de como a Semiótica pode contribuir para o ensino de Língua Portuguesa e, consequentemente, para um ensino mais contemporâneo, condizente com a legislação educacional brasileira e, acima de tudo, com as necessidades dos sujeitos pós-modernos.

\section{AMPLIANDO O UNIVERSO DE ESTUDO DOS SIGNOS: DA SEMIÓTICA GERAL À SEMIÓTICA SOCIAL}

Se numa visão mais tradicional dos estudos do texto, este era percebido apenas numa perspectiva verbal, no mundo contemporâneo, as mudanças comunicacionais, impulsionadas, sobretudo, pelo desenvolvimento das tecnologias digitais, têm contribuído para evidenciar as mais variadas possibilidades de construção textual. Sons, cores, imagens, formas, movimentos, texturas, sinais e gestos, entre outros signos, são agora fundamentais, seja para a constituição das estratégias textuais e discursivas, seja para o entendimento dos processos interacionais. Essas mudanças, evidentemente, requerem sujeitos preparados não apenas para compreender a multiplicidade de signos linguísticos que constituem uma língua, mas também para lidar com a linguagem na sua esfera multissemiótica. Mas de que modo os diferentes signos se constituem? Como produzem significação e sentido na linguagem? Evidentemente, encontrar uma resposta para esses questionamentos é compreender - ainda que de maneira mais geral - os principais fundamentos da Semiótica.

Etimologicamente, o termo semiótica é oriundo da raiz grega semeion, que significa signo. Nesse sentido, a Semiótica é a ciência que estuda os signos e, por isso, "a ciência geral de todas as linguagens" (SANTAELLA, 2007, p.7), diferentemente da Linguística, que realiza o estudo científico da língua. E, embora possa parecer, à primeira vista, que a Semiótica adentra outros campos de estudos que também lidam com os signos, como a Psicologia, a Antropologia, a Biologia, a Musicologia, a Literatura e a própria Linguística, "seu objeto de estudo não é o mesmo deles, uma vez que é o ponto de vista que cria o objeto" (SANTAELLA; NÖTH, 2004, p. 76). No caso da Semiótica,

[...] o que interessa são todos os tipos possíveis de signos, verbais, não-verbais e naturais, seus modos de significação, de denotação e de informação; e todo o seu comportamento e propriedades. Que poderes de referências eles têm, como se contextualizam, como se estruturam em sistemas e processos, como são emitidos, produzidos, 
que efeitos podem provocar nos receptores, como são usados, que conseqüências podem advir deles a curto, médio e longo prazo? Eis aí um quadro de questões que cabe à semiótica investigar. (SANTAELLA; NÖTH, 2004, p.76)

A gênese das investigações no campo semiótico se deu a partir dos estudos de Charles Sanders Peirce. Tendo se dedicado a diferentes áreas - Matemática, Física, Astronomia, Química, Linguística, Psicologia, História, Lógica e Filosofia -, ao desvendar os métodos e fundamentos lógicos desses campos do conhecimento, Peirce pôde relacionar a Lógica com a teoria geral dos signos e, assim, emergem - aos poucos - os fundamentos da Teoria Semiótica.

Mas é importante ressaltar que, embora a teoria peirceana tenha sido a pioneira, a Semiótica se disseminou, quase que simultaneamente, em diferentes espaços no mundo, não apenas por meio dos estudos de Peirce. Na Europa Ocidental, as investigações acerca dos sistemas de signos tiveram ampla divulgação a partir do Curso de Linguística Geral, de Saussure, base fundamental para o desenvolvimento da ciência Linguística e da Semiologia. E, em meados do século XX, estudos propriamente semióticos começaram a se desenvolver nesse território. No mesmo período, na antiga União Soviética, pesquisas realizadas desde o final do século XIX pelos filólogos Viesse-Iovski e Potiebniá também desencadearam novos estudos na área da Semiótica.

Observando os diferentes espaços e percursos seguidos pela Semiótica e a diversidade de tarefas que cabe a essa ciência, não é de se estranhar que, atualmente, ela seja subdividida em três ramos de estudos: a gramática especulativa, a lógica crítica e a retórica especulativa. A primeira se dedica ao estudo das condições gerais dos símbolos e de outros signos que têm caráter significante. Já a segunda observa as condições gerais da referência dos símbolos e outros signos aos seus objetos manifestos. Sendo assim, estuda os tipos de inferências, raciocínios ou argumentos: abdução, indução e dedução. E a terceira, por sua vez, tem como objetivo analisar os métodos a que cada tipo de raciocínio dá origem. Trata-se da metodologia ou metodêutica (PEIRCE, 2005; SANTAELLA, 2008).

Apesar das distinções entre os ramos, compreende-se, em consonância com Santaella (2008), que a gramática especulativa apresenta uma teoria geral de todas as possíveis espécies de signos e, por isso, está na base dos demais ramos semióticos. Sendo assim, as discussões propostas neste trabalho, o qual se volta para um estudo de Semiótica Aplicada ao ensino de Língua Portuguesa, fundamentar-se-ão - inicialmente - nas principais bases teóricas da gramática especulativa elaborada por Peirce.

Mas, para entender a arquitetura filosófica de Peirce, é necessário compreender que todo fenômeno apresenta três categorias que lhe permitem funcionar como signo. São elas: a primeiridade, a secundidade e a terceiridade, categorias as quais o estudioso chama de Cenopitagóricas, em virtude de sua conexão com os números.

A primeiridade faz alusão à originalidade. É o que vem primeiro; “[...] aquilo que é sem referência a qualquer outra coisa dentro dele, ou fora dele, independentemente de toda força e de toda razão" (PEIRCE, 2005, p. 24). De maneira geral, está relacionada à experiência de qualidade das coisas e transmite a ideia de vaguidade, indeterminação.

No entanto, para existir, a qualidade precisa estar materializada. Na verdade, em toda experiência, há algo que sucede o simples ato de sentir. Esse "segundo" elemento, que requer um "primeiro" e pressupõe um "terceiro", está associado às ideias de existência, reação, relação, esforço, resistência. Sendo assim, aquilo que é denominado de secundidade corresponde ao "[...] elemento que, tomado em conexão com a Originalidade, faz de uma coisa aquilo que uma outra a obriga a ser" (PEIRCE, 2005, p. 27). Nesse momento, o que se tem é a ação bruta, que consistirá, conforme Peirce (2005, p. 23), "na ausência de qualquer razão, regularidade ou norma que poderia tomar parte na ação como elemento terceiro ou mediador".

Cabe, então, à categoria nomeada de terceiridade realizar a mediação entre as duas entidades, por meio de uma terceira, a fim de produzir interpretações. Essa categoria está associada ao pensamento articulado e é impulsionada, sobretudo, pelos hábitos, leis e regularidades. Nesse sentido, se a primeiridade está relacionada às possibilidades que emergem no tempo presente e a secundidade se refere à ação bruta ocorrida no tempo pretérito, a terceiridade corresponde ao ser in futuro e representa formas mentais, intenções e expectativas. 
E é justamente por meio dessa compreensão fenomenológica que Peirce conceitua signo como “[...] tudo aquilo que está relacionado com uma segunda coisa, seu Objeto, com respeito a uma Qualidade, de modo tal a trazer uma terceira coisa, seu Interpretante, para uma relação com o mesmo Objeto, e de modo tal a trazer uma Quarta para uma relação com aquele Objeto na mesma forma, $a d$ infinitum" (PEIRCE, 2005, p.28). De modo mais específico, o estudioso explica que um signo ou representâmen é tudo que, de determinada maneira, representa algo - o objeto (elemento perceptível, imaginável ou, até mesmo, inimaginável de certo modo) para alguém, criando em uma mente real ou potencial um signo equivalente, o interpretante. Desse modo, o significado de um signo é outro signo. Ademais, é bom lembrar que o signo não representa um objeto em todos os seus aspectos, mas se refere a um tipo específico de ideia/qualidade: seu fundamento - a face imediatamente perceptível (PEIRCE, 2005).

Sob essa ótica, é possível dizer que um signo pode ser uma palavra, um livro, um filme, um quadro, uma escultura, uma casa, uma escola, uma pessoa, um risco na parede ou qualquer outra coisa, de qualquer espécie, que represente algo e, ao mesmo tempo, crie um efeito interpretativo. Nota-se, assim, que a ideia de signo envolve sempre uma lógica triádica, sendo necessário, por isso, compreender a relação do signo consigo mesmo (seu fundamento), a relação do fundamento com o objeto e a relação do fundamento/objeto com o interpretante.

Nesse sentido, a primeira tricotomia desenvolvida por Peirce, em sua arquitetura semiótica, considera que, no rol das mais variadas propriedades que cada coisa tem, três delas lhe possibilitam funcionar como signo: i) sua qualidade ou fundamento; ii) sua existência e iii) seu caráter de lei. Sendo assim, o signo que em si mesmo pode ser uma qualidade é denominado de qualissigno. Já o signo que se define pela mera propriedade de existir é um sinsigno. Corresponde a um fato ou evento real, ou melhor, a todo existente singular, material e que ocupa um lugar no tempo e no espaço, podendo ser formado por um ou mais qualissignos. Quanto ao signo que é uma lei, pode ser chamado de legissigno.

A segunda tricotomia peirceana - por sua vez - analisa a relação do signo com o objeto que representa. Segundo Peirce (2005), essa relação consiste no fato de que o signo: i) tem um caráter em si mesmo; ii) mantém uma relação existencial com seu objeto ou iii) apresenta alguma relação com seu interpretante. Sob essa ótica, um signo que se refere ao objeto que denota apenas em virtude de seus caracteres próprios, isto é, que tem como fundamento um qualissigno, é considerado um ícone. Já um signo que mantém relação com o objeto que denota em virtude de ser realmente afetado por esse objeto, ou seja, que tem como fundamento um sinsigno, é considerado um indice. Por fim, um signo que se refere ao objeto que denota em virtude de uma lei, ou melhor, que tem que como fundamento um legissigno, é considerado um símbolo.

Quanto à terceira tricotomia elaborada por Peirce, corresponde ao fato de um Interpretante representar um signo como signo de possibilidade, de existência ou de razão. De acordo com o estudioso, um signo que, para seu interpretante, é um signo de possibilidade é um rema. O rema é, em geral, o primeiro efeito causado pelo signo: um interpretante emocional. Conforme Santaella (2008), ícones tendem a produzir mais esse tipo de interpretante. Por outro lado, um signo que, para seu interpretante, é um signo de existência real é um dicissigno. Também chamado de dicente, esse é o segundo efeito que um signo pode provocar: um interpretante energético. Índices tendem a produzir esse tipo de interpretante (SANTAELLA, 2008). Por fim, um signo que, para seu interpretante, é um signo de razão é um argumento. O argumento é o terceiro efeito provocado pelo significado de um signo: um interpretante lógico, sem o qual os símbolos não poderiam significar (SANTAELLA, 2008).

Tais fundamentos são, sem dúvida, imprescindíveis para uma análise geral dos signos, e, por isso, delineiam as bases de um campo mais específico: a Semiótica Social (SS). Mas, se por um lado, a Semiótica Geral, muitas vezes, compreende o signo como uma entidade autônoma, estudando-o fora das relações sociais; por outro, a Semiótica Social é a ciência que realiza a análise dos signos na sociedade e, por isso, compreende os processos de significação como parte de uma construção social. Além disso, por meio desse campo de estudos, os textos são analisados a partir do seu caráter multimodal, ou seja, por meio da complexa inter-relação entre os diferentes modos de representação do significado. 
Historicamente, os estudos sobre Semiótica Social despontam a partir das contribuições de Halliday. Além de introduzir o termo na Linguística, por meio de sua obra Language as Social Semiotic, publicada em 1978, esse estudioso desenvolve as bases da Linguística Sistêmico-Funcional (LSF), teoria que se insere no paradigma dos estudos funcionalistas e busca "estabelecer princípios gerais relacionados ao uso da linguagem" (HALLIDAY, 1978, p. 125, grifo nosso). Desse modo, objetiva compreender e descrever a função e não a forma dos signos.

De acordo com Halliday e Matthiessen (2004), o contexto social é constituído com base na escolha dos falantes a partir da interrelação entre três variáveis: modo (organização simbólica do texto), relações (papéis dos participantes) e campo (natureza da prática social). Essas variáveis se realizam por meio de três funções gerais da linguagem, as quais Halliday (1978) chama de metafunções ideacional (função de representar o mundo), interpessoal (função de estabelecer relações entre os participantes da interação) e textual (função de organizar a mensagem).

Baseando-se nos postulados de Halliday, os pesquisadores Hodge e Kress, em sua obra Social Semiotics (1988), apresentam uma nova dimensão para a análise dos signos. Não se trata de uma ruptura com a tradição, mas de uma reconstrução dos estudos desenvolvidos, de um lado, por Saussure e, de outro, por Peirce, situando-os como parte dos processos sociais. Na referida obra, os autores definem a Semiótica como: "o estudo geral da semiose, isto é, dos processos e efeitos de produção e de reprodução, de recepção e de circulação dos significados em todas as suas formas, utilizadas por todos os tipos de agentes de comunicação" (HODGE; KRESS, 1988, p. 261, tradução nossa). E, ao descrever o objeto de estudo dessa ciência, explicam que a SS focaliza a semiose humana, entendida como um fenômeno inerentemente social em suas origens, funções, contextos e efeitos (HODGE; KRESS, 1988).

Mas, como exposto anteriormente, a SS não abandona conceitos fundamentais da teoria geral dos signos. Por isso, Kress e van Leuween (2006 [1996]), fundamentando-se nos postulados de Peirce, mas - ao mesmo tempo - ampliando a teoria, destacam o potencial representacional e comunicativo da linguagem. No que concerne especificamente ao conceito de representação, os autores explicam:

\begin{abstract}
Nós vemos a representação como um processo em que os produtores de signos, sejam crianças ou adultos, procuram fazer a representação de algum objeto ou entidade, seja ele físico ou semiótico, e em que o seu interesse naquele objeto, no ponto de fazer a representação, é complexo e decorrente da história cultural, social e psicológica do produtor de signos e focado no contexto específico no qual o signo é produzido. (KRESS; VAN LEEUWEN, 2006 [1996], p. 7, tradução nossa)
\end{abstract}

Em consonância com Peirce, os autores consideram que o processo de representação não corresponde ao objeto em si, mas a um aspecto daquilo que é representado. E o signo, por sua vez, "não é a conjunção pré-existente de um significante e um significado, um signo pronto para ser reconhecido, escolhido e usado como é, [...] o significante (a forma) e o significado (o conteúdo) são relativamente independentes um do outro até que sejam reunidos pelo produtor em um signo" (KRESS; VAN LEEUWEN, 2006 [1996], p. 8, tradução nossa).

Nesse contexto, a comunicação é definida como um processo no qual um produto ou evento semiótico é ao mesmo tempo articulado, produzido e interpretado, envolvendo - de um lado - o produtor e - de outro - o interpretante (KRESS; VAN LEUWEEN, 2001). A esses aspectos, os autores acrescentam a ideia de que os significados pertencem à cultura, não a modos semióticos específicos.

Além disso, ao propor uma visão sociossemiótica da linguagem, a SS abarca os significados sociais construídos por meio de uma multiplicidade de formas semióticas. Sendo assim, abre caminhos para o desenvolvimento de trabalhos sobre multimodalidade. Cabe ressaltar aqui que, na ótica da SS, modos são entendidos como "recursos semióticos socialmente enquadrados e culturalmente dados para produzir significado. Imagem, escrita, layout, música, gestos, fala, imagem em movimento, trilha sonora e objetos em 3D são exemplos de modos usados na representação e na comunicação" (KRESS, 2010, p. 79, tradução nossa). Quanto à multimodalidade, diz respeito à integração entre os diferentes modos de constituição do significado (visual, sonoro, espacial, gestual e linguístico). 
A perspectiva sociossemiótica da multimodalidade promove uma ruptura com os modelos tradicionais de estudo da linguagem, nos quais o modo verbal é sobreposto aos demais modos de representação. Na SS, todos os modos possuem o mesmo nível de importância, pois todos apresentam o mesmo potencial representacional e comunicativo e promovem a criação de significados sociais.

Um dos trabalhos pioneiros nessa área foi realizado por Kress e van Leuween (1996), ao proporem uma Gramática do Design Visual (GDV) - método para a análise de imagens a partir dos pressupostos da Gramática Sistêmico-Funcional de Halliday -, revelando que a linguagem visual apresenta estruturas sintáticas passíveis de análise tal como acontece na linguagem verbal e que a LSF pode ser adaptada para o estudo de qualquer sistema semiótico. Apesar disso, é importante considerar que estruturas verbais e visuais apresentam diferentes particularidades e, por isso, representam o mundo de maneira bem diversa.

Assim sendo, na GDV, Kress e van Leuween (2006 [1996]) propõem terminologias específicas para as metafunções visuais: representacional, interativa e composicional, as quais substituem - respectivamente - as metafunções ideacional, interpessoal e textual (propostas por Halliday para a análise da linguagem verbal). A metafunção representacional parte do pressuposto de que "qualquer modo semiótico deve ser capaz de representar aspectos do mundo" (KRESS; VAN LEUWEEN, 2006 [1996], p. 42, tradução nossa). Corresponde, na verdade, às interações e relações conceituais entre as pessoas, lugares e coisas retratadas nas imagens. De modo geral, essa metafunção envolve os diferentes participantes e processos comunicativos.

Os participantes se subdividem em participantes interativos (pessoas reais que produzem e dão sentido às imagens no contexto das instituições sociais, isto é, que participam do ato de comunicação como produtores e/ou receptores) e participantes representados (pessoas, objetos, lugares e coisas que compõem o texto visual). Esses se conectam, muitas vezes, por meio de vetores - elementos que visualmente relacionam dois objetos. Nesse caso, o processo é dinâmico, acional e, por isso, nomeado de narrativo. Mas quando os participantes são apresentados de maneira estática, isto é, sem a presença de vetores, os processos são considerados conceituais.

No que concerne especificamente às estruturas visuais narrativas, representam ações, eventos e processos de mudança. Kress e van Leuween (2006 [1996]) as subdividem em seis categorias, considerando o tipos de vetor e o número/tipo de participantes envolvidos: processos de ação - o Ator é o participante de onde emana o vetor, ou ele mesmo forma o vetor (total ou parcialmente); processos reacionais - o vetor é formado pela direção do olhar do(s) participante(s) representado(s), e o participante que direciona o olhar é um Reagente; processo da fala e processo mental - como o próprio nome indica, corresponde a um tipo especial de vetor (balões) para representar falas e pensamentos dos participantes representados; processos de conversão - ocorrem quando um participante é Meta com relação a um participante e Ator com relação a outro; Simbolismo geométrico - a comunicação se estabelece sem a presença de um participante representado, há apenas um vetor; circunstâncias - referem-se às estruturas visuais nas quais os participantes secundários se relacionam aos principais não através de vetores, mas por outros meios: circunstâncias locativas, de significado e/ou de acompanhamento.

Além dos processos narrativos, Kress e van Leuween (2006 [1996]) destacam - em sua Gramática do Design Visual - os processos conceituais. Esses representam os participantes, considerando aspectos de classe, estrutura e significado e são, respectivamente, denominados de processos classificatórios, analíticos e simbólicos. Os autores ressaltam que, em termos de classe, um participante pode ser subordinado a pelo menos outro participante, o superordenado. E, quando o participante é superordenado com relação a um participante e subordinado em relação a outro, é um participante interordenado. As árvores genealógicas e diagramas representam bem essas relações. Os processos analíticos, por sua vez, relacionam os participantes por meio da estrutura visual (parte-todo). Sendo assim, são constituídos por dois tipos de participantes: um portador (o todo) e os atributos possessivos (as partes). Os mapas exemplificam esse tipo de processo. Quanto aos processos simbólicos, são aqueles que enfatizam os significados. Nesse caso, há dois tipos de participantes: o portador, participante cujo significado ou identidade é estabelecido/a na relação, e o atributo simbólico, participante que representa o significado ou identidade em si mesmo. 
De acordo com Kress e van Leuween (2006 [1996]), além de serem usados para a representação de interações e relações conceituais entre os participantes representados (pessoas, lugares e coisas retratadas nas imagens), os recursos visuais são utilizados para promover outro tipo de interação: a interação entre o produtor e o espectador da imagem. A metafunção que desempenha esse papel é a interativa. A GDV apresenta quatro tipos de relações vinculadas a essa metafunção: contato, distância social, perspectiva e atitude.

O contato é determinado pelo olhar dos participantes. Quando os participantes representados olham para o visualizador, o contato é estabelecido. Nesse caso, há um olhar de demanda. Já em imagens nas quais os participantes não olham diretamente para o visualizador, o olhar é de oferta.

A distância, por sua vez, está relacionada ao enquadramento da imagem. Em imagens de plano aberto, há uma relação de distanciamento entre os participantes. Já as imagens de plano médio demonstram certa proximidade entre os participantes, mas não há uma relação de intimidade. E, finalmente, as imagens de plano fechado revelam maior grau de proximidade/intimidade entre os participantes.

Conforme a GDV, as imagens também podem estabelecer diferentes relações entre os sujeitos por meio da perspectiva (ângulo), e isso implica a possibilidade de expressar atitudes subjetivas em relação aos participantes representados, humanos ou não. No plano horizontal, o ângulo pode ser: oblíquo ou frontal. No primeiro caso, há um envolvimento mínimo entre os participantes; no segundo caso, o envolvimento é máximo. Já no plano vertical, o ângulo pode ser alto ou baixo. "Um ângulo alto, dizem, faz com que o assunto pareça pequeno e insignificante, um ângulo baixo faz com que pareça imponente e incrível" (KRESS; VAN LEUWEEN, 2006 [1996], p. 140, tradução nossa).

Além dos aspectos representativos e interacionais, o processo de construção da imagem envolve os aspectos composicionais. Ao tratar especificamente da metafunção composicional, Kress e van Leuween explicam que "qualquer modo semiótico deve ter a capacidade de formar textos, complexos de signos coerentes internamente entre si e externamente com o contexto no qual e para o qual foram produzidos" (2006 [1996], p. 43, tradução nossa). De maneira geral, essa metafunção relaciona os significados representacionais e interativos da imagem por meio de três sistemas inter-relacionados: valor da informação, saliência e enquadramento.

O valor da informação é atribuído às imagens a partir da inserção dos elementos em diferentes zonas: esquerda e direita, superior e inferior, centro e margem. De acordo com os autores da GDV, os recursos visuais localizados na linha horizontal estabelecem a relação dado/novo. Do mesmo modo, a linha vertical salienta a relação ideal/real. Quanto às dimensões centro e margem, correspondem - respectivamente - ao núcleo da informação e aos elementos periféricos (subservientes ao núcleo da imagem).

Em relação ao segundo elemento composicional, a saliência, corresponde aos elementos utilizados para atrair a atenção do visualizador em diferentes graus, podendo criar uma hierarquia de importância entre os elementos. Quanto maior for o peso de um elemento, maior será a sua saliência.

Já o terceiro elemento composicional, o enquadramento, diz respeito à presença ou não de dispositivos que desconectam ou conectam elementos numa determinada imagem (linhas divisórias ou linhas de quadro reais), significando que tais elementos pertencem ou não um ao outro em dado sentido. Quanto mais forte for o enquadramento de um elemento, mais ele é apresentado como uma unidade separada de seu conjunto de formação.

De acordo com Kress e van Leuween (2006[1996]), as metafunções representacional, interativa e composicional podem ser aplicadas não apenas a imagens, mas também a recursos visuais compostos, isto é, a textos que combinam o visual com o verbal e/ou com outras semioses. Nesses casos, o todo não deve ser simplesmente tratado como a soma dos significados das partes; pelo contrário, as partes é que devem ser vistas como elementos integrados que interagem e se afetam mutuamente. Eis aí um desafio ainda em aberto no campo semiótico. 
Portanto, considerando a necessidade de expandir os métodos de análise de textos na atualidade e, sobretudo, de preparar o sujeito contemporâneo para lidar com textos multissemióticos, dois questionamentos-chave que surgem aqui são: Quais as orientações da legislação educacional brasileira para o trabalho com análise semiótica na educação básica? Como promover o ensino de Semiótica no contexto escolar, desenvolvendo uma análise integrada das semioses, em textos multimodais? Embora tenham sido publicados alguns trabalhos sobre o ensino de Semiótica nos últimos anos, muitas vezes esses textos: i) não têm como foco o trabalho com as multissemioses (como SIMÕES, 2017; 2018); ii) apresentam propostas didáticas que se centram em apenas um gênero textual (a exemplo de GOMES, 2021); iii) não apresentam uma proposta de ensino embasada nas orientações normativas da Base Nacional Comum Curricular (como o artigo de PEREIRA, 2020). Tudo isso revela a necessidade do desenvolvimento de outros estudos na área. Sendo assim, as seções a seguir promoverão uma discussão em torno dos supracitados questionamentos.

\section{PRÁTICAS DE ANÁLISE SEMIÓTICA NO CONTEXTO ESCOLAR: O QUE PROPÕE A BNCC?}

Pensar nos processos de ensino e aprendizagem de uma língua no contexto atual é pensar, sobretudo, numa didática de ensino voltada para o trabalho com diferentes processos de significação que envolvam a infinidade de signos que estão à nossa volta. No que concerne especificamente à disciplina Língua Portuguesa, compreende-se que não é possível dar conta das práticas de leitura, oralidade e escrita sem englobar a multiplicidade de linguagens e gêneros multimodais presentes na sociedade contemporânea e, portanto, sem envolver a Semiótica.

Nota-se, no entanto, que, embora o ensino de análise semiótica esteja presente nas atividades escolares (através da análise de variados textos e linguagens), nem sempre é desenvolvida por meio de uma didática teoricamente fundamentada. Esse fato está relacionado, de certo modo, às lacunas existentes no processo de formação de professores na área de Letras. Observa-se, por exemplo, que disciplinas que tratam da Teoria Semiótica são inseridas na grade curricular dos cursos de licenciatura em Letras, na maioria das vezes, como optativas (isso quando estão presentes no currículo dos cursos).

Tal fato pode ser comprovado por meio de uma breve análise da grade curricular dos cursos de Licenciatura em Letras, com habilitação em Língua Portuguesa, oferecidos pelas universidades públicas federais e estaduais na Bahia - Universidade Federal da Bahia (UFBA), Universidade Federal do Recôncavo da Bahia (UFRB), Universidade do Estado da Bahia (UNEB), Universidade Estadual de Santa Cruz (UESC), Universidade Estadual do Sudoeste da Bahia (UESB) e Universidade da Integração Internacional da Lusofonia Afro-Brasileira (UNILAB). Dessas universidades, apenas duas - a UNILAB e a UNEB (Campus I) - oferecem a disciplina Semiótica como componente optativo nos cursos de Letras. Mas, na UNEB, trabalha-se especificamente com Semiótica da narrativa (na perspectiva greimasiana). Os cursos de Licenciatura em Letras das demais universidades, quando muito, propõem um trabalho com leitura, produção e análise de textos contemplando a diversidade de signos. É o caso de componentes como: Introdução às Linguagens audiovisuais e Literatura Visual (UFRB), Leitura de Produções Artísticas e Leitura de Produções da Mídia (UFBA), entre outros.

Além disso, nota-se que, apenas recentemente, o trabalho com a Semiótica na educação básica vem sendo orientado pelos documentos educacionais brasileiros. Nos Parâmetros Curriculares Nacionais de Língua Portuguesa (PCN) para o ensino fundamental (terceiro e quarto ciclos), publicados em 1998, os conteúdos são organizados em três grandes blocos de conteúdos: Língua Oral, Língua Escrita e Análise e reflexão sobre a língua. Como se observa, a análise semiótica não era contemplada. O mesmo acontece nos Parâmetros Curriculares Nacionais do Ensino Médio (PCNEM), publicados nos anos 2000. As quatro competências da Área de Língua Portuguesa enfatizam o trabalho com a linguagem estritamente verbal. Não consta nesses documentos qualquer orientação para o trabalho com a multiplicidade de signos. Isso pode ser justificado pelo fato de que foram publicados no final do século XX. E, somente na primeira década do século XXI, é que as tecnologias digitais se propagaram e possibilitaram o desenvolvimento de novas linguagens visuais, sonoras, espaciais e, sobretudo, a ampliação dos textos multimodais. 
Portanto, é apenas, a partir de 2017, com a Base Nacional Comum Curricular, que o trabalho com Semiótica na educação básica passa a ser orientado pelos documentos educacionais brasileiros ${ }^{3}$. A BNCC é um documento de caráter normativo que define o conjunto de aprendizagens essenciais a serem desenvolvidas pelos estudantes ao longo das etapas e modalidades da educação básica, de modo que tenham assegurados seus direitos de aprendizagem e desenvolvimento. Por isso, a Base está estruturada de modo a explicitar as competências que devem ser desenvolvidas na Educação Infantil, no ensino fundamental e no ensino médio, em diferentes etapas do conhecimento.

Em relação ao trabalho com linguagens, a Base orienta que - tanto no ensino fundamental quanto no ensino médio - as atividades estejam centradas no trabalho com diferentes linguagens:

A área de Linguagens, no Ensino Fundamental, está centrada no conhecimento, na compreensão, na exploração, na análise e na utilização das diferentes linguagens (visuais, sonoras, verbais, corporais), visando estabelecer um repertório diversificado sobre as práticas de linguagem e desenvolver o senso estético e a comunicação com o uso das tecnologias digitais. No Ensino Médio, o foco da área de Linguagens e suas Tecnologias está na ampliação da autonomia, do protagonismo e da autoria nas práticas de diferentes linguagens; na identificação e na crítica aos diferentes usos das linguagens, explicitando o seu poder no estabelecimento de relações, na apreciação e na participação em diversas manifestações artísticas e culturais; e no uso criativo das diversas mídias. (BRASIL, 2017, p.471)

No intuito de orientar efetivamente as atividades a serem desenvolvidas no ensino fundamental, além de trazer as Áreas do Conhecimento e as Competências Especificas de Área, a BNCC apresenta os Componentes Curriculares e as Competências Específicas de Componente, bem como as Unidades temáticas, Objetos de conhecimento e Habilidades a serem desenvolvidas em cada série, nos distintos componentes curriculares.

No Componente Língua Portuguesa, a Base sugere que as atividades privilegiem quatro eixos: Oralidade, Leitura/escuta, Produção de textos e Análise linguística/semiótica e, ao mesmo tempo, considerem - nos anos iniciais - os seguintes campos de atuação: campo da vida cotidiana, campo artístico-literário, campo das práticas de estudo e pesquisa e campo da vida pública. Nos anos finais, o campo da vida cotidiana é substituído pelo jornalístico-midiático e o campo da vida pública transforma-se em campo de atuação na vida pública.

O eixo Análise linguística/semiótica, em especial, é descrito na BNCC como uma prática transversal, pois envolve os procedimentos e estratégias (meta)cognitivas de análise e avaliação consciente, durante os processos de leitura e de produção de textos (orais, escritos e multissemióticos), bem como efeitos de sentido referentes às formas de composição dos textos, considerando-se os diferentes gêneros e a situação de produção, e aos estilos adotados nos textos (BRASIL, 2017).

O documento também salienta que a análise específica de textos orais envolverá tanto os elementos próprios da fala quanto os elementos paralinguísticos e cinésicos. Já em relação aos textos multissemióticos, a BNCC propõe uma análise que:

[...] levará em conta as formas de composição e estilo de cada uma das línguagens que os integram, tais como plano/ângulo/lado, figura/fundo, profundidade e foco, cor e intensidade nas imagens visuais estáticas, acrescendo, nas imagens dinâmicas e performances, as características de montagem, ritmo, tipo de movimento, duração, distribuição no espaço, sincronização com outras linguagens, complementaridade e interferência etc. ou tais como ritmo, andamento, melodia, harmonia, timbres, instrumentos, sampleamento, na música. (BRASIL, 2017, p.81)

Observa-se, desse modo, que a BNCC restringe a análise de textos multimodais aos elementos composicionais e estilísticos. Os aspectos representacionais e interacionais não são considerados. Além disso, há um descompasso entre a perspectiva teórica

\footnotetext{
${ }^{3}$ Embora houvesse trabalhos publicados no Brasil, na área de Semiótica e Ensino, até o momento a legislação educacional brasileira não apresentava orientações para subsidiar o ensino de análise semiótica. Apenas a análise linguística era contemplada nos documentos.
} 
apresentada no documento e os objetos de conhecimento do eixo, os quais mencionam apenas elementos linguísticos: fonoortografia, morfosssintaxe, sintaxe, semântica, variação linguística e elementos notacionais da escrita.

Sendo assim, no trabalho com análise linguística/semiótica nos anos iniciais, a BNCC traz habilidades mais voltadas para a alfabetização e a ortografização; os aspectos linguísticos são sobrepostos aos semióticos. Isso acontece, especialmente, nas habilidades comuns a todas as séries iniciais. Em nenhuma dessas habilidades é feita qualquer referência a recursos semióticos distintos do verbal. Já nas habilidades relativas a cada série ou ciclo $\left(1^{\circ} / 2^{\circ}\right.$ ano e $3^{\circ} / 4^{\circ} / 5^{\circ}$ ano $)$ algumas habilidades propostas enfatizam as formas composicionais de gêneros orais, visuais e multimodais.

No que diz respeito aos anos finais do ensino fundamental, a maior parte das habilidades de análise linguístico-semiótica que precisam ser desenvolvidas a longo prazo (desde o $6^{\circ}$ até o $9^{\circ}$ ano), privilegiam a multimodalidade. O Quadro 1 comprova, por exemplo, que o trabalho com multimodalidade é destacado em habilidades de análise linguística/semiótica propostas para o $6^{\circ}$ ao $9^{\circ}$ ano, em diferentes campos de atuação.

Quadro 1: Exemplos de habilidades que valorizam o trabalho com os recursos sonoros, visuais e multimodais no eixo Análise linguística/semiótica $\left(6^{\circ}\right.$ ao $9^{\circ}$ ano do ensino fundamental)

\begin{tabular}{c|l}
\hline $\begin{array}{c}\text { CAMPO DE ATUA- } \\
\text { ÇÃO }\end{array}$ & \multicolumn{1}{c}{ HABILIDADES } \\
$\begin{array}{c}\text { Campo } \\
\text { jornalístico-midiá- } \\
\text { tico }\end{array}$ & $\begin{array}{l}\text { (EF69LP19) Analisar, em gêneros orais que envolvam argumentação, os efeitos de sentido de elementos típicos } \\
\text { da modalidade falada, como a pausa, a entonação, o ritmo, a gestualidade e expressão facial, as hesitações etc. }\end{array}$ \\
\hline $\begin{array}{c}\text { Campo das práticas } \\
\text { e estudo }\end{array}$ & $\begin{array}{l}\text { (EF69LP40) Analisar, em gravações de seminários, conferências rápidas, trechos de palestras, dentre outros, a } \\
\text { construção composicional dos gêneros de apresentação [...], os elementos paralinguísticos (tais como: tom e vo- } \\
\text { lume da voz, pausas e hesitações - que, em geral, devem ser minimizadas -, modulação de voz e entonação, } \\
\text { ritmo, respiração etc.) e cinésicos (tais como: postura corporal, movimentos e gestualidade significativa, expres- } \\
\text { são facial, contato de olho com plateia, modulação de voz e entonação, sincronia da fala com ferramenta de apoio } \\
\text { etc.), para melhor performar apresentações orais no campo da divulgação do conhecimento. }\end{array}$ \\
\hline $\begin{array}{c}\text { Campo } \\
\text { artístico- } \\
\text { literário }\end{array}$ & $\begin{array}{l}\text { (EF69LP54) Analisar os efeitos de sentido decorrentes da interação entre os elementos linguísticos e os recursos } \\
\text { paralinguísticos e cinésicos, como as variações no ritmo, as modulações no tom de voz, as pausas, as manipula- } \\
\text { ções do estrato sonoro da linguagem, obtidos por meio da estrofação, das rimas e de figuras de linguagem como } \\
\text { as aliterações, as assonâncias, as onomatopeias, dentre outras, a postura corporal e a gestualidade, na declamação } \\
\text { de poemas, apresentações musicais e teatrais, tanto em gêneros em prosa quanto nos gêneros poéticos [...] }\end{array}$ \\
\hline
\end{tabular}

Fonte: BNCC (2017)

No entanto, ao apresentar as habilidades específicas por série ou ciclo $\left(6^{\circ} / 7^{\circ}\right.$ ano e $8^{\circ} / 9^{\circ}$ ano $)$, o documento traz apenas habilidades linguísticas. As multissemioses são excluídas. A Figura 1, que evidencia as habilidades específicas para o $6^{\circ}$ e $7^{\circ}$ ano do ensino fundamental, no item Todos os Campos de Atuação, comprova essas afirmações. 


\begin{tabular}{|c|c|c|}
\hline \multirow{2}{*}{ OBJETOS DE CONHECIMENTO } & \multicolumn{2}{|l|}{ HABILIDADES } \\
\hline & GPNO & 7 ANO \\
\hline \multirow[t]{5}{*}{ Morfossintaxe } & & $\begin{array}{l}\text { (EFOZLPOB) Identificar, em textos lidos } \\
\text { ou de produçấ própria, adjetivos que } \\
\text { ampliam o sentido do substantivo sujeito ou } \\
\text { complemento verbal. }\end{array}$ \\
\hline & & $\begin{array}{l}\text { (EFO7LPO9) Identificar, en textos lidos ou } \\
\text { de produçấo própria, advérbios e locuçōes } \\
\text { adverbiais que ampliam o sentido do verbo } \\
\text { núcleo da oração. }\end{array}$ \\
\hline & $\begin{array}{l}\text { (EFO6LP07) Identificar, em textos, periodos } \\
\text { compostos por oraçóes separadas por virgula } \\
\text { sema utilização de conectivos, nomeando-os } \\
\text { como periodos compostos por coordenaçấ. }\end{array}$ & \\
\hline & $\begin{array}{l}\text { (EFO6LPOB) Identificar, em texto ou sequència } \\
\text { textual, oraçóes como unidades constituidas } \\
\text { em tomo de um núcleo verbal e periodos } \\
\text { como conjunto de oraçóes conectadas. }\end{array}$ & $\begin{array}{l}\text { (EFOZLP10) Utilizar, ao produzir texto, } \\
\text { conhecimentos linguisticos e gramaticais: } \\
\text { modos e tempos verbais, concordáncia } \\
\text { nominal e verbal, pontuaçáo etc. }\end{array}$ \\
\hline & $\begin{array}{l}\text { (EFO6LP09) Classificar, em texto ou sequencia } \\
\text { textual, os periodos simples compostos. }\end{array}$ & $\begin{array}{l}\text { (EFOZPII) Identificar, em textos lidos ou } \\
\text { de produçấo própria, periodos compostos } \\
\text { nos quais duas oraçós são conectadas por } \\
\text { virgula, ou por conjunç̄es que expressem } \\
\text { soma de sentido (conjunçấo "e") ou oposiçăo } \\
\text { de sentidos (conjunçōes "mas", "porém"). }\end{array}$ \\
\hline Sintaxe & $\begin{array}{l}\text { (EFO6LP10) Identificar sintagmas nominais } \\
\text { e verbais como constituintes imediatos da } \\
\text { oraçâ. }\end{array}$ & \\
\hline Elementos notacionais da escrita/morfossintaxe & $\begin{array}{l}\text { (EFO6LPI1) Utilizar, ao produzir texto. } \\
\text { conhecimentos linguisticos e gramaticais. } \\
\text { tempos verbais, concordância nominal e } \\
\text { verbal, regras ortográficas, pontuação etc. }\end{array}$ & \\
\hline $\begin{array}{l}\text { Semântica } \\
\text { Coesāo }\end{array}$ & $\begin{array}{l}\text { (EFO6LP12) Utilizar, ao produzir texto, } \\
\text { recursos de coesáo referencial (nome e } \\
\text { pronomes), recursos semánticos de sinonimia, } \\
\text { antonimia e homonimia e mecanismos de } \\
\text { representaça de diferentes vazes (discurso } \\
\text { direto e indireto). }\end{array}$ & $\begin{array}{l}\text { (EFOTLP12) Reconhecer recursos de } \\
\text { coesáo referencial: substituiçóes lexicais (de } \\
\text { substantivos por sinónimos) ou pronominais } \\
\text { (uso de pronomes anafóricos - pessoais, } \\
\text { possessivos, demonstrativos). }\end{array}$ \\
\hline \multirow[t]{2}{*}{ Coesão } & \multicolumn{2}{|c|}{$\begin{array}{l}\text { (EF67LP36) Utilizar, ao produzir texto, recursos de coesäo referencial (léxica e pronominaD) e } \\
\text { sequencial e outros recursos expressivos adequados ao género textual. }\end{array}$} \\
\hline & & $\begin{array}{l}\text { (EFOTLP13) Estabelecer relaçōes entre } \\
\text { partes do texto, identificando substituiçōes } \\
\text { lexicais (de substantivos por sinónimos) ou } \\
\text { pronominais (uso de pronomes anafóricos - } \\
\text { pessoais, possessivos, demonstrativos), que } \\
\text { contribuem para a continuidade do texto. }\end{array}$ \\
\hline Sequencias textuais & \multicolumn{2}{|c|}{$\begin{array}{l}\text { (EF67LP37) Analisar, em diferentes textos, os efeitos de sentido decorrentes do uso de recursos } \\
\text { linguistico-discursivos de prescrição, causalidade, sequéncias descritivas e expositivas e } \\
\text { ordenação de eventos. }\end{array}$} \\
\hline Modalizaçâo & & $\begin{array}{l}\text { (EFOTLP14) Identificar, em textos, os } \\
\text { efeitos de sentido do uso de estratégias de } \\
\text { modalização e argumentatividade. }\end{array}$ \\
\hline Figuras de linguagem & \multicolumn{2}{|c|}{$\begin{array}{l}\text { (EF67LP38) Analisar os efeitos de sentido do uso de figuras de linguagem, como comparação. } \\
\text { metäfora, metonimia, personificação, hipérbole, dentre outras. }\end{array}$} \\
\hline
\end{tabular}

Figura 1: Habilidades de Análise linguística/semiótica, presentes no item Todos os campos de atuação $\left(6^{\circ}\right.$ e $7^{\circ}$ ano do ensino fundamental) Fonte: BNCC (2017, p.172-175)

Nota-se, portanto, um descompasso, sobretudo nos anos finais do ensino fundamental, entre as habilidades comuns a todas as séries e aquelas destinadas a cada série. Evidentemente, as habilidades que são compartilhadas em todas as séries possuem uma demanda particular em cada momento do processo de aprendizagem. Nesse sentido, é necessário deixar claro para o docente o que é possível desenvolver em cada série, a partir de uma mesma habilidade.

Mas, se por um lado, pode-se dizer que o trabalho com os elementos sonoros, visuais e multissemióticos não é enfatizado nas habilidades específicas de cada série, no eixo de Análise linguística/semiótica; por outro lado, observa-se que os elementos multissemióticos são valorizados nos demais eixos de conhecimento. Esses aspectos revelam que a Semiótica perpassa todos os eixos, pois não há como ler ou produzir textos (orais, escritos, visuais, sonoros e multissemióticos) sem conhecer os recursos (multi)semióticos. No entanto, o caráter transversal da Semiótica não impede um trabalho específico, voltado para a discussão de 
aspectos representacionais, interacionais e composicionais que envolvem as multissemioses; pelo contrário, ratifica a importância do eixo Análise semiótica.

Com relação ao ensino médio, a BNCC prioriza o trabalho com Linguagens e Tecnologias, a partir de cinco campos de atuação: i) campo da vida pessoal; II) campo das práticas de estudo e pesquisa; iii) campo jornalístico-midiático; iv) campo de atuação na vida pública; v) campo artístico. Assim sendo, o trabalho com Língua Portuguesa é proposto com base em diferentes competências e habilidades que envolvem tanto os campos de atuação quanto as seguintes práticas de linguagem: leitura, escuta, produção de textos (orais, escritos, multissemióticos) e análise linguística/semiótica. Mas, diferentemente do ensino fundamental, a Base não expõe as habilidades de cada componente para cada série. Apresenta apenas as Competências Específicas de Área e as Habilidades de cada componente, organizadas nos diferentes campos de atuação. Não há uma separação das habilidades por eixo de conhecimento. Todas as habilidades são referentes a todos os eixos e boa parte delas valoriza os recursos sonoros, visuais ou multimodais, bem como os gêneros digitais. A Figura 2, ao destaca algumas habilidades contidas no item Todos os campos de atuação, comprova essas afirmações.

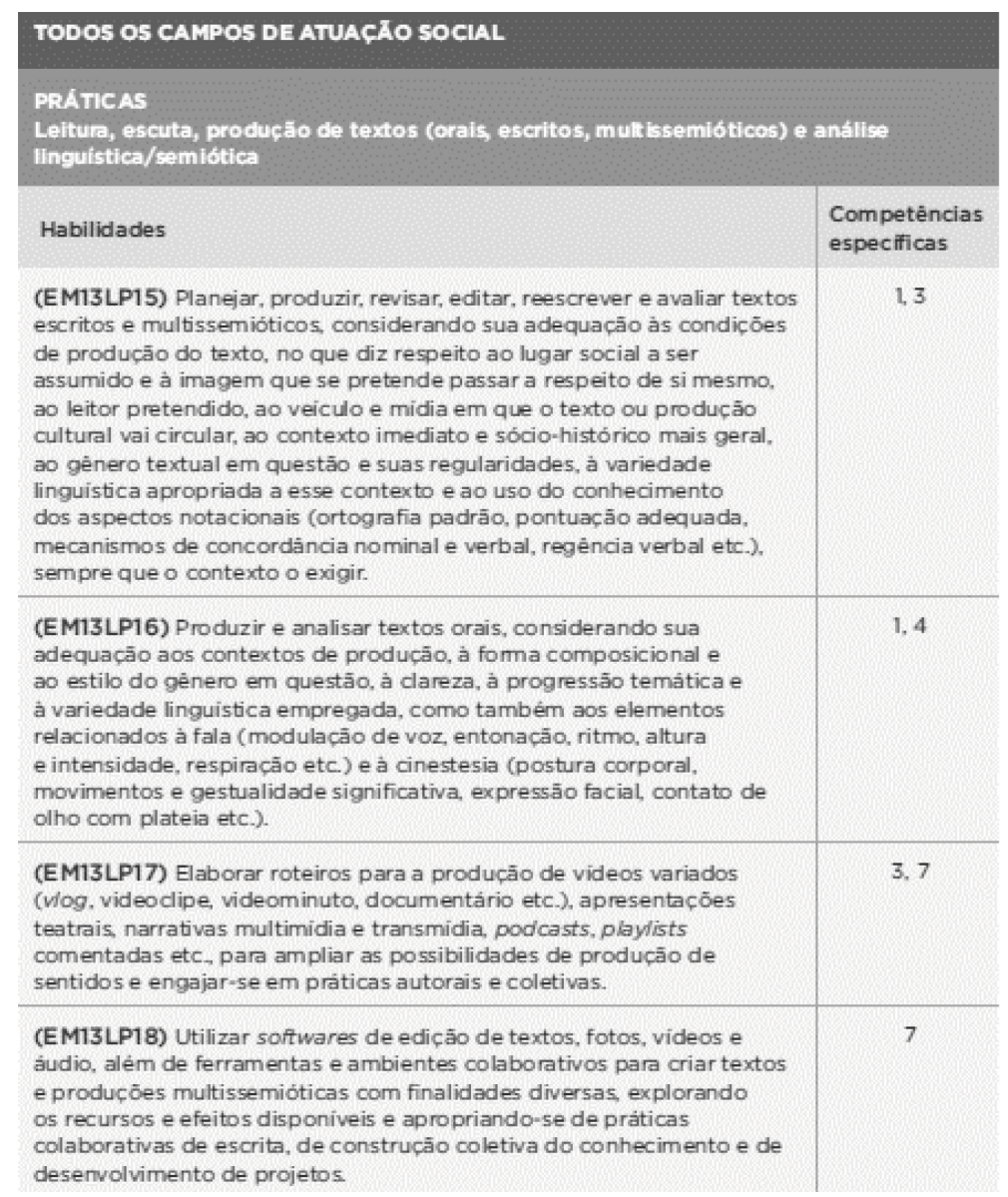

Figura 2: Algumas habilidades que valorizam o trabalho com os recursos sonoros, visuais e multimodais no eixo Análise linguística/semiótica (Ensino médio/ Todos os campos de atuação)

Fonte: BNCC (2017)

A lacuna da BNCC nesse nível de ensino é, realmente, não separar as habilidades por eixo de conhecimento/série. Nesse sentido, cabe aos currículos escolares realizar essa segmentação. Além disso, embora a Base seja um documento norteador, não indica as estratégias metodológicas que podem ser utilizadas pelo professor. Esse não é o objetivo do documento. Por isso, uma pergunta ainda fica sem resposta em relação ao eixo de Análise semiótica: Como promover o ensino de Semiótica no contexto escolar, 
desenvolvendo uma análise integrada das semioses em textos multimodais? No intuito de responder a esse questionamento, a seção seguinte apresenta uma proposta didática para o trabalho com análise multissemiótica.

\section{O ENSINO DE SEMIÓTICA NA EDUCAÇÃO BÁSICA: UM MODELO DIDÁTICO PARA A ANÁLISE DE TEXTOS MULTIMODAIS}

Considerando a importância do trabalho com textos multimodais em sala de aula, de modo a contemplar as atuais necessidades comunicativas dos sujeitos contemporâneos, objetiva-se, nesta seção do artigo, apresentar uma proposta didática para o trabalho com análise semiótica, a qual envolva a integração entre diferentes semioses.

A proposta aqui apresentada tem como fundamentos alguns aspectos da teoria de Peirce (2005), Halliday (1978) e Kress e van Leuween (2006 [1996]), por isso, propõe a integração entre os principais sistemas semióticos: linguístico (escrito e oral), sonoro, visual, gestual e espacial, a partir das metafunções: representacional, interacional e composicional. Compreende-se, no entanto, que há uma distinção entre esses elementos do ponto de vista hierárquico. Os sistemas sonoro, visual e linguísticos são primários, pois constroem significados independentemente dos outros modos. Os demais sistemas, por sua vez, estão sempre relacionados ao visual, sonoro e/ou linguístico e, portanto, são considerados sistemas secundários.

Corroborando essas ideias, Santaella (2005) argumenta que há raízes lógicas e cognitivas específicas que determinam a constituição do verbal, do visual, do sonoro, e de toda a variedade de processos sígnicos que eles geram. De acordo com a hipótese das matrizes da linguagem e pensamento, elaborada pela autora, a linguagem sonora está relacionada à primeiridade, assim como a linguagem visual está associada à secundidade e a linguagem verbal à terceiridade. Apoiando-se, desse modo, nas categorias de Peirce e nos tipos dos signos que se originam dessas categorias, a autora evidencia que: "A lógica da matriz sonora, sob a dominância da sintaxe, é mais primordial, estando na base das outras matrizes. A lógica da matriz visual, englobando a sintaxe e sob a dominância da forma, está na base da matriz verbal cuja lógica discursiva se constitui pela incorporação da sintaxe e da forma” (SANTAELLA, 2005, p.79). Sob essa ótica, o trabalho com textos multimodais em sala de aula deve partir da inter-relação entre elementos sonoros, visuais e linguísticos para, posteriormente, verificar como elementos gestuais, tácteis, espaciais, corporais etc. se associam aos modos primários, contribuindo para a construção dos significados. Para tanto, o processo de ensino e aprendizagem deve ser metodologicamente orientado por um modelo didático que privilegie os seguintes aspectos: o que ensinar (conteúdos), por que ensinar (objetivos) e como ensinar (métodos) (cf. HAYDT, 2011; LIBÂNEO, 2013).

Na primeira etapa, a fim de delinear o que e por que ensinar, de acordo com Haydt (2011), o professor precisa delinear seis elementoschave: público-alvo (clientela), objetivo, conteúdo, etapas da aprendizagem, recursos e estratégias de avaliação. A esses elementos, acrescentam-se, neste trabalho: problema/contexto, escopo e ambiente de aprendizagem. O Quadro 2 especifica esses elementos.

\begin{tabular}{c|c|c}
\multicolumn{2}{c}{ Elementos } & \multicolumn{1}{c}{ Quadro 2: Elementos norteadores das ações didáticas } \\
\hline $\mathbf{1}$ & Público-alvo & Análise das caracs metodológicas \\
\hline $\mathbf{2}$ & Problema/contexto da clientela. \\
\hline $\mathbf{3}$ & Escopo & $\begin{array}{l}\text { Análise contextual: dificuldades apresentadas pelos alunos no que concerne à análise } \\
\text { semiótica de diferentes gêneros textuais. }\end{array}$ \\
\hline $\mathbf{4}$ & Conteúdo & $\begin{array}{l}\text { Definição das habilidades que serão desenvolvidas (com base na BNCC), bem como } \\
\text { do tema, gêneros e textos que serão analisados. }\end{array}$ \\
\hline
\end{tabular}




\begin{tabular}{c|c|l}
$\mathbf{5}$ & Objetivos & $\begin{array}{l}\text { Delimitação dos objetivos; análise da clareza e alcance dos objetivos, bem como de sua } \\
\text { aderência às habilidades que serão desenvolvidas. }\end{array}$ \\
\hline $\mathbf{6}$ & Ambiente & $\begin{array}{l}\text { Delimitação do ambiente (casa, sala de aula etc.), bem como da interface principal (no } \\
\text { caso da aprendizagem em contexto digital). }\end{array}$ \\
\hline $\mathbf{7}$ & $\begin{array}{c}\text { Etapas de aprendizagem/ } \\
\text { atividades }\end{array}$ & $\begin{array}{l}\text { Definição das etapas de aprendizagem; } \\
\text { Definição das atividades a serem desenvolvidas em cada etapa. }\end{array}$ \\
\hline $\mathbf{8}$ & Recursos & $\begin{array}{l}\text { Definição dos recursos disponíveis e necessários; análise de seu envolvimento em cada } \\
\text { atividade. }\end{array}$ \\
\hline $\mathbf{9}$ & Estratégias de avaliação & Definição das estratégias de avaliação.
\end{tabular}

Fonte: autoria própria

Em relação ao como ensinar, sugere-se aqui, uma proposta centrada na Pedagogia dos Multiletramentos (COPE; KALANTZIS, 2009). O conceito de multiletramentos está associado, por um lado, à multiplicidade cultural e linguística das sociedades pós-modernas e, por outro, à multiplicidade e integração de variados modos de constituição do significado, por meio da utilização de diferentes semioses (cf. NLG, 1996). Na primeira versão da Pedagogia dos Multiletramentos, as noções teóricas de Design se transformam em quatro dimensões pedagógicas: prática situada, instrução explícita, enquadramento crítico e prática transformada. Posteriormente, com a reformulação da teoria, os atos pedagógicos - antes considerados dimensões pedagógicas - são subdivididos nas seguintes etapas: experiência, conceitualização, análise e aplicação (cf. COPE; KALANTZIS, 2009). Sendo assim, propõe-se que o trabalho com textos multimodais em sala de aula englobe as referidas etapas e privilegie a análise dos sistemas representacional, interativo e composicional

O Quadro 3 detalha a proposta, que foi elaborada no intuito de nortear o trabalho com textos multissemióticos, sobretudo no ensino médio, a partir do que requerem as competências específicas para a Área de Linguagens e suas Tecnologias. Mas as orientações gerais e a especificidade do trabalho dependem, evidentemente, de um planejamento mais amplo e contextualmente situado (como sugerido no Quadro 2).

Quadro 3:Orientação didática geral para o trabalho com textos multimodais

\section{ETAPA 1: EXPERIMENTAÇÃO}

Nessa etapa, valorizam-se os conhecimentos prévios dos estudantes em relação aos elementos que compõem os sistemas representacionais, interativos e composicionais do texto. Sendo assim, sugere-se o desenvolvimento de atividades que promovam reflexões sobre o texto, a partir de questionamentos gerais voltados para os diferentes sistemas de análise

\begin{tabular}{c|l}
\hline NÍVEIS & \multicolumn{1}{c}{ ESPECIFICAÇÕES METODOLÓGICAS } \\
\hline $\begin{array}{c}\text { Nível } \\
\text { representacional }\end{array}$ & $\begin{array}{l}\text { Questionamentos norteadores da análise: } \\
\text { Como o texto representa o mundo? Quais são as semioses utilizadas para essa representação? Como cada } \\
\text { semiose contribui para a representação geral dos objetos, pessoas, coisas, lugares, enfim, para a representação do } \\
\text { mundo? }\end{array}$ \\
\hline Nível interativo & $\begin{array}{l}\text { Questionamentos norteadores da análise: } \\
\text { Como os elementos presentes no texto propiciam a interação entre autor e leitor? O modo como o texto foi } \\
\text { produzido permite proximidade ou distanciamento entre os interlocutores? O autor expressa atitude subjetiva } \\
\text { ou objetiva em relação aos participantes representados? }\end{array}$
\end{tabular}




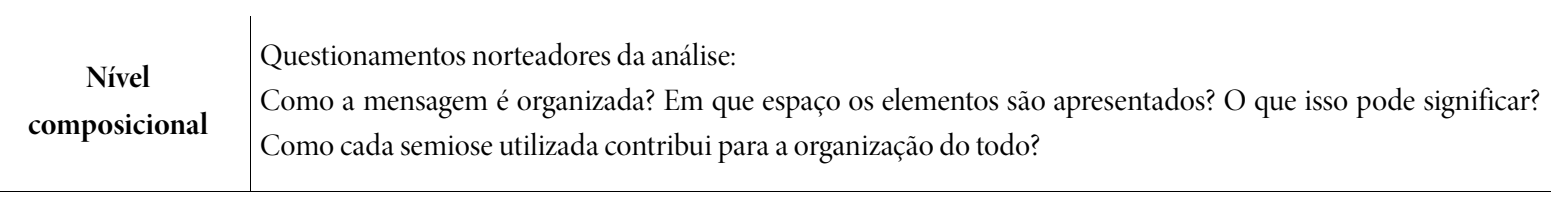

\section{ETAPA 2: CONCEITUALIZAÇÃO}

Nessa etapa, os estudantes devem desenvolver uma metalinguagem explícita acerca dos elementos que compõem os sistemas representacionais, interativos e composicionais do texto. Para tanto, o professor deve levar o aluno a construir conceitos semióticos, tanto por meio da observação/análise de um texto, quanto através da comparação entre esse e outros textos, através de diferentes módulos de atividades.

\begin{tabular}{|c|c|}
\hline NÍVEIS & ESPECIFICAÇÕES METODOLÓGICAS \\
\hline \multirow[t]{2}{*}{$\begin{array}{l}\text { Nível } \\
\text { representacional }\end{array}$} & 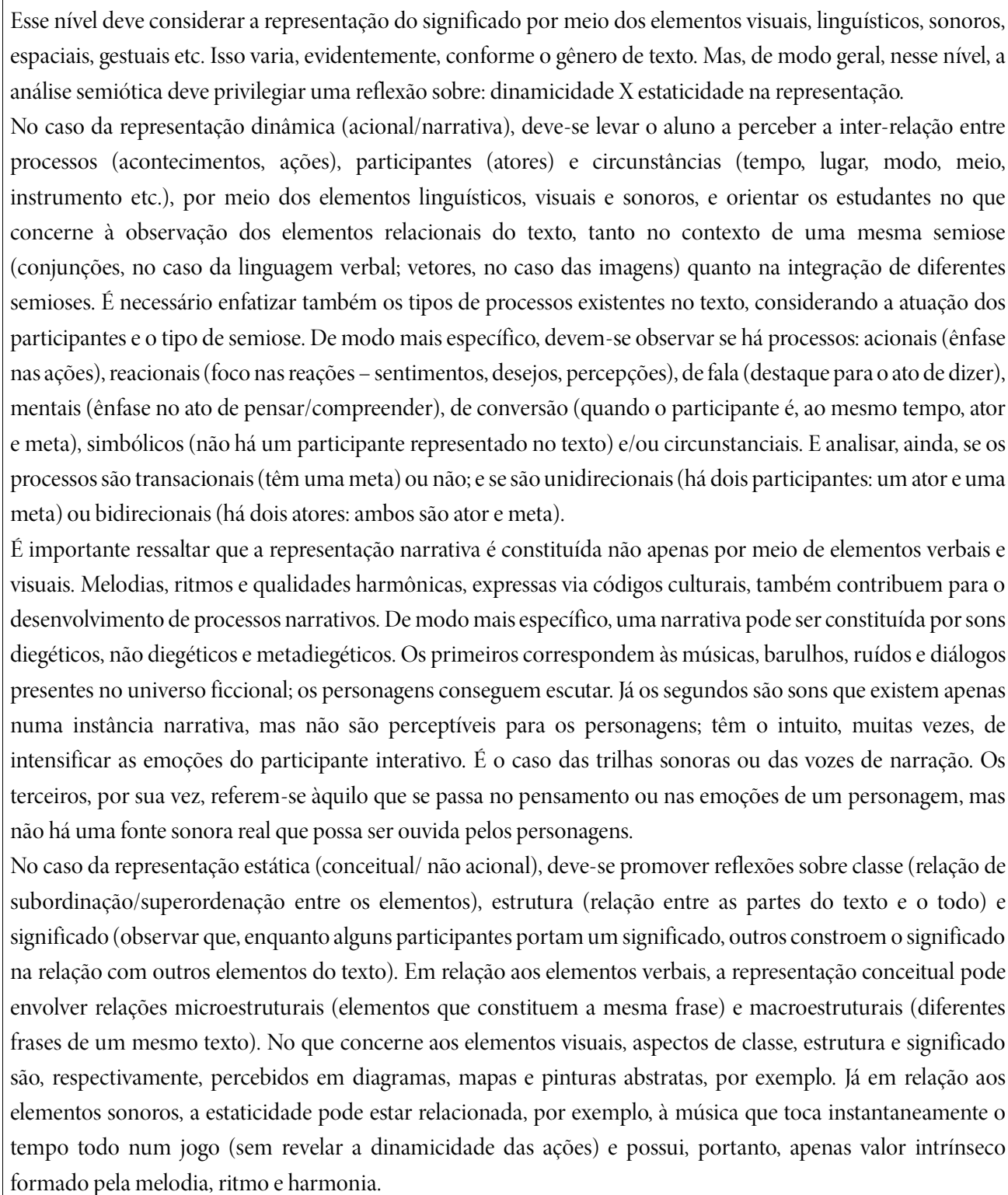 \\
\hline & $\begin{array}{l}\text { Esse nível deve evidenciar a interação entre os interlocutores, mostrando de que modo elementos apresentados } \\
\text { no texto propiciam a proximidade ou distanciamento entre autor e leitor. Para tanto, o professor, deve dialogar } \\
\text { com os estudantes acerca de três aspectos: } \\
\text { 1) A função do texto: dar ou demandar algo (informações/ bens e serviços); }\end{array}$ \\
\hline
\end{tabular}


2) O nível da relação entre os participantes: íntimo, pessoal ou impessoal;

3) O modo como são expressas as atitudes: objetivamente ou subjetivamente.

De modo mais específico, o professor deve mostrar que, quando a função é de oferta, há um contato menor entre os interlocutores. Já a função de demanda revela maior contato entre os participantes. No caso específico das

Nível interativo imagens, o plano mais aberto ou mais fechado também distancia ou aproxima socialmente os interlocutores assim como o ângulo frontal evidencia envolvimento e o ângulo oblíquo, afastamento. O ângulo alto, por sua vez, representa insignificância e o baixo, imponência. Na música, por sua vez, os sons diegéticos, metadiegéticos e não diegéticos promovem, nessa sequência, uma escala de maior distanciamento para maior proximidade social entre os interlocutores. No caso dos games, a interatividade musical é marcada por meio dos sons não-lineares os quais são acionados a partir das ações diretas do jogador (Activity), em oposição aos sons que normalmente comunicam ambientes, clima, atmosfera (Setting). Os primeiros sons revelam, obviamente, maior contato entre participante interativo e participante representado. E tudo isso evidencia as possibilidades que o produtor tem de expressar atitudes subjetivas ou não em relação aos participantes representados nos diferentes textos multimodais. Sendo assim, o professor também precisa mostrar que o autor pode construir um texto no intuito de expressar ou não atitudes subjetivas em relação aos participantes representados. Imagens científicas e técnicas, como diagramas, mapas e gráficos, geralmente codificam uma atitude objetiva; o inverso ocorre em relação às imagens abstratas. Do mesmo modo, músicas que se referem a algo concreto, sem possibilidade de múltiplas interpretações, são, geralmente, consideradas mais objetivas. Ademais, em muitos momentos, a ausência de música dá um tom mais objetivo às narrativas, evitando o desenvolvimento de relações emocionais. É importante lembrar que ausência de música, nesse caso, é diferente de silêncio, que também dá um tom emocional à narrativa.

Por meio desse nível, os estudantes devem compreender como os significados representacionais e interativos se relacionam na composição do texto. Para tanto, o professor deve promover atividades que mostrem não apenas como as orações se organizam internamente (tema/rema), mas evidenciem, sobretudo, a composição do texto como um todo, demonstrando os diferentes espaços onde os elementos aparecem (direita/esquerda, parte superior/parte inferior, centro/margens), a depender do valor de cada informação. No caso dos elementos sonoros, a disposição dos recursos no início, meio ou final do texto também representa diferentes valores. Outro elemento que deve ser enfatizado pelo professor é a saliência de alguns elementos em detrimento de outros, podendo até mesmo gerar uma hierarquia. Num texto, pode haver destaque para uma dentre várias semioses e/ou para um elemento dentro de uma mesma semiose. No último caso, serão relevantes elementos como: tamanho e fonte das letras, recursos de marcação, cores e tonalidades, melodia, harmonia e ritmo sonoro. Por fim, ainda no nível composicional, o professor deve mostrar a presença ou não de dispositivos que desconectam ou conectam os elementos numa mesma semiose e, ao mesmo tempo, relacionam diferentes semioses. O aluno deve ficar ciente de que, quanto mais conectados estiverem os elementos, mais eles se apresentarão como pertencentes um ao outro, constituindo uma unidade de informação.

ETAPA 3: ANÁLISE

Nessa etapa, os sujeitos devem analisar diferentes textos, inter-relacionando as diferentes semioses e os diferentes sistemas de análise.

\section{ETAPA 4: APLICAÇ̃̃O}

Os estudantes aplicarão os conhecimentos (conceituais, procedimentais e atitudinais) em diferentes contextos de uso da linguagem.

Fonte: autoria própria

É importante ressaltar que a proposta didática foi subdividida em diferentes etapas/níveis visando a uma melhor sistematização das informações acerca de cada metafunção. Mas, obviamente, quando o professor desenvolve o trabalho com uma dada metafunção, ele precisa promover - ao mesmo tempo - a experimentação, a conceitualização, a análise e a aplicação. E, à medida que novas metafunções vão sendo trabalhadas, aquelas anteriormente aprendidas também vão sendo consideradas, pois o objetivo final é que o aluno possa analisar textos nas mais diferentes situações, aplicando os conhecimentos aprendidos nas distintas etapas de atividades. 
Fica evidente, então, que - longe de ser uma proposta de aplicação pontual - esse é um modelo didático que deve ser desenvolvido a longo prazo, por meio de diferentes módulos de atividades que englobem variados gêneros textuais.

Tal modelo também pode ser adaptado para o trabalho com análise semiótica nas séries iniciais e finais do ensino fundamental, considerando as habilidades que devem ser desenvolvidas nessa etapa educacional, pois acredita-se que estratégias de aprendizagem desenvolvidas por meio da experimentação, conceitualização, análise e aplicação de conhecimentos relativos aos sistemas representacionais, interativos e composicionais podem contribuir para a compreensão global dos textos multimodais.

Portanto, sem esgotar as possibilidades de análise semiótica, o esboço geral aqui apresentado é apenas um dos caminhos que o professor pode seguir para que o trabalho com textos multissemióticos no contexto educacional ocorra não de maneira intuitiva, mas fundamentado no que propõem a Semiótica Social, a Teoria da Multimodalidade e os documentos educacionais brasileiros.

\section{CONCLUSÃO}

O presente artigo teve como objetivo apresentar um modelo didático para o trabalho com análise multissemiótica na educação básica, no intuito de colaborar com os docentes da área de Língua Portuguesa e, ao mesmo tempo, contribuir com o desenvolvimento de processos de ensino e aprendizagem articulados às novas propostas educacionais e às necessidades dos sujeitos contemporâneos.

Considera-se que o processo de análise de textos, numa perspectiva semiótica, precisa ser desenvolvido a partir de um plano geral de trabalho elaborado a partir dos seguintes elementos: público-alvo, problema/contexto, escopo, conteúdo, objetivo, ambiente, etapas de aprendizagem, recursos e estratégias de avaliação. É esse plano geral que norteará o desenvolvimento dos processos de experimentação, conceitualização, análise e aplicação de conhecimentos representacionais, interativos e composicionais.

Sendo assim, ao unir a proposta teórico-metodológica da Pedagogia dos Multiletramentos com os pressupostos da Gramática do Design Visual para a elaboração de um modelo didático geral, procura-se contribuir, de maneira global, para as práticas de ensino de Semiótica na educação básica e - paralelamente a isso - reiterar a necessidade da elaboração de modelos didáticos mais específicos para o trabalho com diferentes gêneros textuais/discursivos que contemplem, pelo menos, três aspectos fundamentais para a análise de textos multimodais: i) a integração das semioses; ii) o desenvolvimento de atividades que valorizem a experimentação, a conceitualização, a análise e a aplicação dos conhecimentos; iii) o estudo do texto, considerando os elementos representacionais, interativos e composicionais. Mas o modelo apresentado neste trabalho é apenas um esboço geral. Muitas propostas ainda precisam ser delineadas, muitos caminhos metodológicos ainda precisam ser construídos.

Portanto, espera-se que este trabalho possa alcançar o propósito de instigar uma discussão teórico-metodológica no campo da Semiótica, gerando novas contribuições didáticas e favorecendo, especialmente, professores e estudantes da educação básica.

\section{REFERENCIAS}

BRASIL. Ministério da Educação. Base Nacional Comum Curricular. Brasília: MEC, 2017.

BRASIL. Parâmetros Curriculares Nacionais: ensino Médio. Brasília: MEC, 2000.

BRASIL. Parâmetros Curriculares Nacionais: terceiro e quarto ciclos do ensino fundamental. Língua Portuguesa. Brasília: MEC/SEF, 1998. 
GOMES, F. M. C. A semiótica e a análise de gêneros multimodais: uma proposta de ensino de língua portuguesa na educação básica. SEDA - Revista de Letras da Rural, Rio de Janeiro, v. 5, n. 12, p. 140-158, 15 jan. 2021.

HALLIDAY, M. A. K. Language as social semiotic. London: Edward Arnold, 1978.

HALLIDAY, M. A. K; MATTHIESSEN, C. An introduction to functional grammar. 3. ed. London: Hodder Education, 2004.

HAYDT, R. C. C. Curso de didática geral. São Paulo: Ática, 2011.

HODGE, R.; KRESS, G. Social Semiotics. London: Polity Press, 1988.

KRESS, G. Multimodality: a social semiotic approach to contemporary communication. New York: Routledge, 2010.

KRESS, G.; VAN LEEUWEN, T. Multimodal discourse: the modes and media of contemporary communication. London: Arnold, 2001.

KRESS, G.; VAN LEEUWEN, T. Reading images: the grammar of visual design. London; New York: Routledge, 2006 [1996].

LIBÂNEO, J. C. Didática. 2. ed. São Paulo: Cortez, 2013.

PEIRCE, C. S. Semiótica. Trad. José Teixeira Coelho Neto. 3. ed. São Paulo: Perspectiva, 2005.

PEREIRA, J. N. Abordagem semiótica de gêneros multimidiáticos. Linguagem em Foco, v. 11, n. 1, p. 110-120,2020.

SANTAELLA, L. Matrizes da linguagem e pensamento: sonora, visual, verbal: aplicações na hipermídia. 3 ed. São Paulo: Iluminuras; FAPESP, 2005.

SANTAELLA, L. O que é semiótica. São Paulo: Brasiliense, 2007. (Coleção Primeiros Passos)

SANTAELLA, L. Semiótica aplicada. São Paulo: Cengage Learning, 2008.

SANTAELLA, L.; NÖTH, W. Comunicação e semiótica. São Paulo: Hacker Editores, 2004.

SALVADOR, C. C. (org.). Psicologia do ensino. Porto Alegre: Artmed, 2000.

SIMÕES, D. (org.). Semiótica \& ensino: letramento pela imagem. RJ: Dialogarts, 2017.

SIMÕES, D. (org.). Semiótica, pesquisa e ensino. RJ: Dialogarts, 2018.

THE NEW LONDON GROUP. A pedagogy of multiliteracies: Designing social futures. Harvard Educational Review, v. 66, n.1, 6092, 1996.

\section{()(1) $\circledast$}

Recebido em 13/12/2020. Aceito em 8/03/2021. 